\title{
Gambaran Tingkat Kepatuhan Membaca Label Pangan pada Mahasiswa Fakultas Sains dan Teknologi Universitas Al Azhar Indonesia
}

\author{
Dina Widiawati ${ }^{1}$, Ema Komalasari ${ }^{1}$ \\ ${ }^{1}$ Program Studi Teknologi Pangan, Fakultas Sains dan Teknologi, Universitas Al Azhar Indonesia \\ Komplek Masjid Agung Al Azhar, Jl. Sisingamangaraja, Jakarta Selatan 12110 \\ Penulis untuk Korespondensi/E-mail: dina.widiawati@uai.ac.id
}

\begin{abstract}
Abstrak-Kesadaran konsumen dalam membaca label pangan dan untuk memahami isi label pangan masih sangat rendah. Diperlukan analisis mengenai tingkat kepatuhan mahasiswa dalam membaca label pangan, sehingga mahasiswa memiliki pemahaman yang lebih baik terhadap label pangan. Responden pada penelitian ini adalah mahasiswa dari Fakultas Sains dan Teknologi Universitas Al Azhar Indonesia angkatan 2015-2018. Metode pengambilan data pada penelitian ini adalah melalui kuisioner. Responden akan mengisi sendiri kuisioner yang diberikan dengan mengikuti instruksi yang akan dijelaskan sebelum pengisian kuisioner oleh tim pengambil data. Responden pada penelitian ini berjumlah 90 orang dengan jumlah perempuan 53,33\% dan laki-laki 46,67\%. Pengetahuan responden mengenai label pangan ada pada kategori baik yaitu $82,22 \%$ dan kategori cukup $17,78 \%$. Sedangkan untuk tingkat kepatuhan, responden yang memiliki tingkat kepatuhan tertinggi berada pada kategori cukup yaitu $61,11 \%$, kategori baik $36,67 \%$, dan kategori kurang $2,22 \%$. Data pada penelitian ini menunjukkan bahwa pengetahuan responden mengenai label pangan ada pada kategori baik dan tingkat kepatuhan dalam membaca label pangan ada pada kategori cukup.
\end{abstract}

Abstract- Consumer awareness in reading food labels and understanding the contents of food labels are still very low. An analysis is needed on the level of student compliance in reading food labels, so students have a better understanding of food labels. Respondents in this study were students from the Faculty of Science and Technology of Al Azhar University Indonesia class of 2015-2018. The data collection method in this study was through a questionnaire. Respondent's will fill in the questionnaire given themselves by following the instructions that will be explained before filling out the questionnaire by the data collection team. Respondents in this study numbered 90 people with $53,33 \%$ women and 46,67\% men. Respondents knowledge about food labels is in the good category that is $82,22 \%$ and $17,78 \%$ enough category. As for the level of adherence, respondents who had the highest level of adherence were in the sufficient category, namely $61,11 \%$, the good category $36,67 \%$, and the less $\mathbf{2 , 2 2 \%}$ category. The data in this study indicate that respondents' knowledge about food labels is in the good category and the level of compliance in reading food labels is in the sufficient category.

Keywords-Food Label, Food Label Knowledge, Decision-Making,Level of Compliance

\section{PENDAHULUAN}

M asyarakat modern saat ini lebih memilih makanan siap saji dan makanan dalam kemasan karena lebih praktis, mudah dibawa, dan mudah dikonsumsi. Pergeseran kebiasaan ini perlu dicermati karena pangan dalam kemasan memiliki kandungan sodium, gula, asam lemak jenuh, asam lemak trans, maupun pengawet, yang mana jika kita konsumsi secara terus - menerus dalam jumlah yang berlebihan dapat berbahaya bagi kesehatan tubuh. Selain itu, kecenderungan masyarakat untuk mengkonsumsi makanan kemasan intensitasnya meningkat dikarenakan kesibukan, gaya hidup, dan lain sebagainya. Mengkonsumsi makanan kemasan dan cepat saji dengan porsi lebih besar dari ukuran penyajian semakin meningkatkan prevalensi penyakit-penyakit degenerative di dunia[1]. 
Label pangan adalah setiap keterangan mengenai pangan olahan yang berbentuk gambar, tulisan, kombinasi keduanya, atau bentuk lain yang disertakan pada pangan olahan, dimasukkan kedalam, ditempelkan pada, atau merupakan bagian kemasan pangan [2]. Melalui label pangan, diharapkan masyarakat mendapatkan informasi dasar yang penting tentang produk pangan yang akan dikonsumsi, seperti komposisi produk, cara penanganan produk, tanggal kedaluwarsa, label halal, takaran per sajian, dan kandungan gizi yang terdapat pada produk pangan.

Kesadaran konsumen dalam membaca label pangan dan kemampuan masyarakat untuk memahami isi label pangan masih sangat rendah. Survei yang dilakukan oleh Badan Perlindungan Konsumen Nasional (BPKN) pada tahun 2007 menyebutkan bahwa hanya sebesar 6,7\% konsumen di Indonesia yang memperhatikan kelengkapan label pangan suatu produk[3]. Kajian Kepedulian Keamanan Pangan Masyarakat tahun 2015 yang dilakukan oleh Direktorat Surveilan dan Penyuluhan Keamanan Pangan Badan Pengawas Obat dan Makanan (BPOM) menunjukkan bahwa hanya $25,3 \%$ konsumen yang mengecek komposisi makanan, sedangkan 37,1\% sering, 34,5\% jarang, dan $3,1 \%$ tidak pernah mengecek komposisi pangan. Survei yang dilakukan oleh BPOM tahun 2015 terhadap 450 mahasiswa dan mahasiswi di DKI Jakarta menunjukkan hanya $33 \%$ yang memiliki pemahaman baik terhadap label pangan dan $67 \%$ sisanya tidak memahami dengan baik label pangan[4]. Pemahaman dan pengaplikasian aturan dalam memilih label pangan seharusnya diterapkan oleh setiap orang, khususnya oleh mahasiswa. Mahasiswa sebagai agen perubahan diharapkan mampu memahami dan mengaplikasikanpemilihan label pangan yang baik guna menjadi contoh bagi masyarakat.

Dari data yang ada, diperlukan analisis mengenai pengetahuan dan tingkat kepatuhan mahasiswa sehingga mahasiswa yang merupakan agen perubahan ini memiliki pemahaman yang lebih baik terhadap label pangan. Adanya pemahaman dan kepatuhan yang baik mengenai label pangan akan memberikan dampak positif yaitu akan lebih selektif dalam memilih produk pangan kemasan yang akan dikonsumsi. Perilaku membaca label produk pangan kemasan dapat digunakan sebagai salah satu usaha dalam tindakan preventif dan promotif dalam memelihara kesehatan.

\section{METODE}

\section{Desain, Tempat, dan Waktu}

Pengambilan data dilaksanakan pada Bulan Agustus 2019. Penelitian ini dilaksanakan di Fakultas Sains dan Teknologi Kampus Universitas Al Azhar Indonesia, Jakarta. Metode yang digunakan pada penelitian ini dilakukan dengan pembagian kuisioner kepada responden. Responden akan mengisi sendiri kuisioner yang diberikan dengan mengikuti instruksi yang akan dijelaskan sebelum pengisian kuisioner oleh tim pengambil data. Kuisioner yang telah diisi langsung dikumpulkan pada hari yang sama. Hal ini dilakukan agar tidak terjadi bias pada saat pengumpulan data.

Pengisian kuisioner mengenai pengetahuan responden mengenai label pangan dinyatakan dengan skala Guttman yaitu jika jawaban benar nilainya 1 (satu) dan jawaban salah nilainya 0 (nol) [5], sedangkan untuk tingkat kepatuhan dalam membaca label pangan dinyatakan dengan skala Likert yaitu 1 = Sangat Tidak Setuju; 2 = Tidak Setuju; 3= Setuju; dan 4= Sangat Setuju [6]. Penelitian ini menggunakan desain potong lintang (Cross Sectional) yaitu sebuah penelitian dimana data pada variable dependen dan variable independen diambil secara bersamaan serta tidak berkelanjutan.

\section{Cara Penarikan Sampel}

Penarikan sampel pada penelitian ini berdasarkan pada jumlah populasi mahasiswa Fakultas Sains dan Teknologi semester 2, 4, 6, dan 8 angkatan 2015-2018, Universitas Al Azhar Indonesia dan menggunakan rumus SLOVIN sebagai berikut[7]:

$$
\begin{aligned}
& \mathrm{n}=\frac{\mathrm{N}}{1+\mathrm{Ne}^{2}} \ldots(1) \\
& \mathrm{n}=\frac{334}{1+(334) 0.1^{2}} \\
& \mathrm{n}=77
\end{aligned}
$$

Keterangan:

$\mathrm{n}=$ Jumlah mahasiswa yang dijadikan sebagai sampel

$\mathrm{N}=$ Jumlah populasi mahasiswa FST semester 2, 4, 6, dan 8

$\mathrm{e}=$ Batas kesalahan sampel (10\%)

Jumlah sampel penelitian ini dengan menggunakan rumus SLOVIN berjumlah 77 sampel. Namun, jumlah yang dijadikan sampel pada penelitian ini berjumlah 90 orang, hal ini dilakukan untuk 
memperkecil terjadinya kesalahan dalam penarikan sampel. Metode dalam penentuan sampel di setiap angkatan dilakukan secara acak dan ditentukan berdasarkan jumlah mahasiswa dalam masing masing jurusan. Sebaran sampel dilakukan menggunakan teknik penarikan sampel melalui Multistage Sampling. Teknik tersebut dapat menggunakan rumus sebagai berikut:

$$
\mathrm{ni}=\frac{\mathrm{Ni}}{\mathrm{N}} \times \mathrm{n} \ldots
$$

Keterangan:

$$
\begin{array}{ll}
\mathrm{ni} & =\text { Jumlah sampel tiap subpopulasi } \\
\mathrm{Ni} & =\text { Total subpopulasi } \\
\mathrm{N} & =\text { Total Populasi } \\
\mathrm{n} & =\text { Jumlah sampel yang diambil }
\end{array}
$$

\section{Pengolahan dan Analisis data}

Pengolahan data pada penelitian ini menggunakan Statistical Package for Social Science (SPSS). Data tersebut dianalisis secara deskriptif yang meliputi rata-rata, nilai minimum, nilai maksimum, dan standar deviasi. Pertanyaan didalam kuisioner sebelumnya sudah di uji validitas dan reliabilitasnya sebelum disebarkan kepada responden.

\section{HASIL DAN PEMBAHASAN}

\section{Karakteristik Umum Responden}

Bebera pakar karakteristik demografi yang sangat penting untuk memahami konsumen (responden) dari penelitian ini yaitui nformasi mengenai karakteristik umum responden yang terdiri dari jenis kelamin, usia, uang saku/bulan, dan jumlah keluarga. Karakteristik umum responden dapat dilihat pada Tabel 1.

Tabel 1. KarakteristikUmumResponden

\begin{tabular}{clccccc}
\hline No & Karakteristik & \multicolumn{4}{c}{ Semester } & Jml. \\
\cline { 3 - 6 } & & $\mathbf{2}$ & $\mathbf{4}$ & $\mathbf{6}$ & $\mathbf{8}$ & $(\mathbf{\%})$ \\
\hline $\mathbf{1}$ & JenisKelamin & & & & & \\
& Laki-laki & 16 & 6 & 12 & 8 & 46,67 \\
\multirow{2}{*}{$\mathbf{2}$} & Perempuan & 17 & 8 & 15 & 8 & 53,33 \\
& Usia & & & & & \\
& $<19$ tahun & 6 & 0 & 0 & 0 & 6,67 \\
& $19-21$ tahun & 26 & 21 & 17 & 10 & 82,22 \\
\multirow{3}{3}{} & $>$ Uang Saku & 1 & 1 & 2 & 6 & 11,11 \\
& $<$ Rp 800.000 & 18 & 5 & 6 & 4 & 36,67 \\
& Rp 800.000 - & 12 & 11 & 8 & 6 & 41,11 \\
& 1.500 .000 & & & & & \\
\hline
\end{tabular}

\begin{tabular}{llccccc}
\hline No & Karakteristik & \multicolumn{4}{c}{ Semester } & Jml. \\
\cline { 3 - 6 } & & $\mathbf{2}$ & $\mathbf{4}$ & $\mathbf{6}$ & $\mathbf{8}$ & $(\boldsymbol{\%})$ \\
\hline \multirow{3}{*}{4} & >Rp1.500.000 & 3 & 6 & 5 & 6 & 22,22 \\
& JumlahKeluarga & & & & \\
& Kecil & 15 & 11 & 9 & 6 & 45,56 \\
& Sedang & 18 & 11 & 10 & 10 & 54,44 \\
& Besar & 0 & 0 & 0 & 0 & 0 \\
\hline
\end{tabular}

Sebagian besar responden pada penelitian ini berjenis kelamin perempuan yaitu 53,33\% dan laki - laki dengan jumlah 46,67\%. Beberapa penelitian menunjukkan bahwa konsumen laki - laki memiliki kecenderungan membaca label pangan lebih rendah daripada konsumen perempuan. Jenis kelamin perempuan $(44,9 \%)$ lebih sering membaca informasi nilai gizi pangan kemasan dengan lakilaki $(29,8 \%)$ [8]. Dari segi usia, sebagian besar responden berusia sekitar 19-21 tahun dengan persentase $82,22 \%$. Rentang usia responden masuk kedalam kategori usia dewasa awal. Hal tersebut akan mempengaruhi kepeduliannya terhadap label pangan, karena di usia tersebut mulai tumbuh rasa tanggung jawab baik terhadap diri sendiri maupun orang lain [9]. Rentang usia 18-24 tahun merupakan usia yang paling umum untuk mahasiswa dengan status mahasiswa aktif dengan tingkat sarjana dan tergolong dalam usia dewasa awal[10].

Jika dilihat dari komponen uang saku responden perbulan, paling banyak uang saku per bulansekitarRp 800.000 - Rp 1.500 .000 yaitu $41,11 \%$. Keluarga dari responden berada pada criteria keluarga sedang yang berjumlah 5-7 orang dengan persentase $54,44 \%$. Menurut Badan Kependudukan dan Keluarga Berencana Nasional (BKKBN) (1998) besar keluarga dibagi menjadi tiga kategori, yaitu keluarga kecil ( $\leq 4$ orang), sedang (5-7 orang), dan besar ( $\geq 8$ orang) [11].

\section{Sumber Memperoleh Informasi Label Pangan}

Sumber informasi yang telah digunakan responden dalam memperoleh informasi mengenai label pangan terdiri dari media, buku, kuliah, teman, dan lainnya. Adapun data mengenai sumber dari responden dalam memperoleh informasi label pangandapatdilihat pada Gambar 1. 


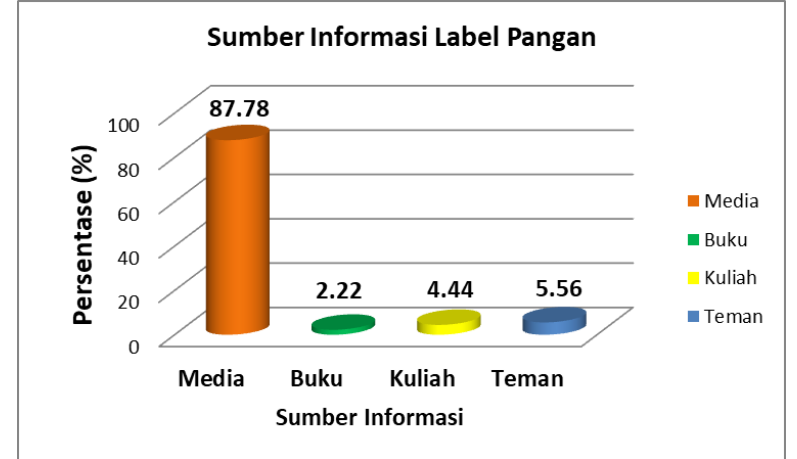

Gambar 1. Sumberinformasi label pangan

Berdasarkan data pada Gambar 1 bahwa sumber informasi terbanyak responden diperoleh dari media dengan persentase sebesar $(87,78 \%)$. Sumber informasi mengenai label pangandi peroleh responden juga dari teman $(5,56 \%)$, perkuliahan $(4,44 \%)$, dan buku $(2,22 \%)$. Peran media paling penting dalam penyebaran suatu informasi di era digital ini. Sumber informasi yang diperoleh dari media yaitu 36,67\%[10]. Sebanyak 34,7\% responden memperoleh informasi label pangan dari media internet [8].

\section{Intensitas dalam Membaca Label Pangan}

Intensitas responden dalam membaca label pangan suatu produk dibagi menjadi kategori tidak pernah, jarang, sering, dan selalu. Data mengenai seberapa sering responden dalam membaca label pangan dapat dilihat pada Gambar 2.

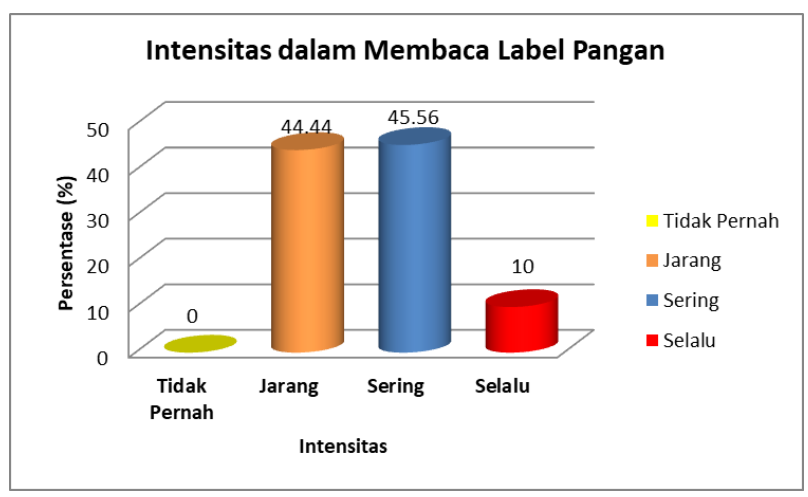

Gambar 2. Intensitas dalam membaca label pangan

Berdasarkandata pada Gambar 2, sebanyak 45,56\% responden sering membaca label pangan, diikuti oleh intensitas jarang $(44,44 \%)$ dan selalu $(10 \%)$.

\section{Seberapa Penting Label Pangan}

Kategori dalam penyebaran kuisioner pada bagian ini dibagi menjadi beberapa kategori yaitu, tidak penting, ragu-ragu, penting dan sangat penting. Gambaran responden mengenai seberapa penting membaca label pangan dapat dilihat pada Gambar 3.

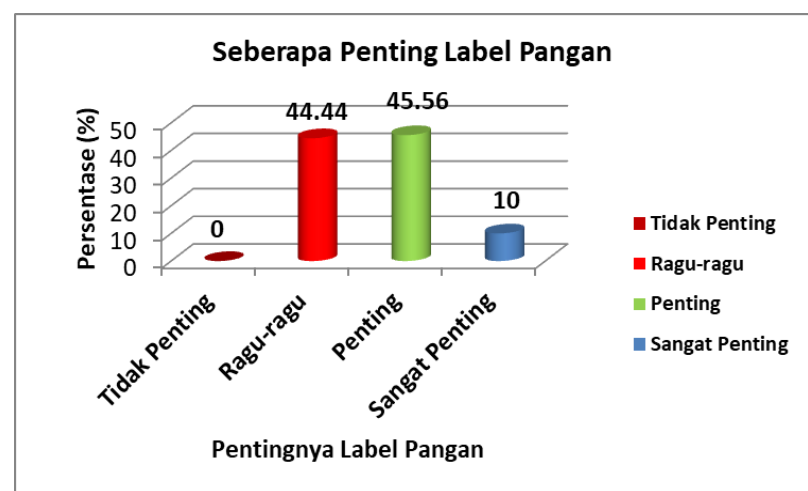

Gambar 3. Seberapapenting label pangan

Data yang diperoleh berdasarkan Gambar 3 menunjukkan bahwa $45,56 \%$ responden menyatakan penting untuk mencantumkan label dalam produk pangan kemasan. Sedangkan responden yang menjawab ragu-ragu yaitu 44,44\% dan $10 \%$ menjawab sangat penting. Sikap raguragu dapat muncul karena responden juga mendapat informasi label pangan bukan hanya dari produk pangan kemasan yang mereka konsumsi, namun informasi tersebut didapat dari saudara, teman, kenalandan informasi tersebut bias berbeda dengan yang dicantumkan pada label sehingga mereka menjadi ragu akan pentingnya pencantuman label pangan pada produkpangankemasan[12]. Sikap ragu-ragu pada kebenaran informasi nilai gizi dan nilai produk pangan kemasan juga dapat menjadi penghalang dalam memanfaatkan informasi nilai gizi[13].

\section{Pengaruh Membaca Label Pangan dalam Keputusan Membeli Produk}

Pengaruh membaca label pangan dalam keputusan membeli produk pada penelitian ini dibagi menjadi dua kategori, yaitu ada pengaruh (Ya) dan tidak ada pengaruh (Tidak). Gambaran responden mengenai kriteriainidapatdilihat pada Gambar 4.

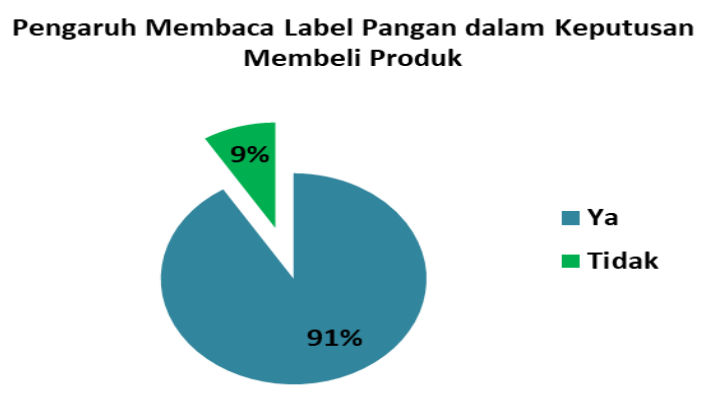

Gambar 4. Pengaruhmembaca label pangandalam keputusan membeliproduk 
Berdasarkan data pada Gambar 4 menunjukkan bahwa 82 orang $(91,11 \%)$ memilih membaca label pangan sebelum membeli produk dan 8 orang $(8,89 \%)$ tidak dipengaruhi pembacaan label pangan ketika akan membeli suatu produk pangan. Tingginya kepedulian responden terhadap produk yang akan dibeli merupakan bentuk keingintahuan responden mengenai keamanan pangan produk yang dibeli.

\section{Pengetahuan Label Pangan}

Pengetahuan konsumen yaitu semua informasi yang dimiliki oleh konsumen mengenai berbagai macam produk, baik barang ataupun jasa, serta pengetahuan lainnya yang terkait dengan barang atau jasa tersebut, dan informasi yang berhubungan dengan fungsinya sebagai konsumen[14]. Gambaran mengenai pengetahuan responden mengenai label pangan dapat dilihat pada Gambar 5.

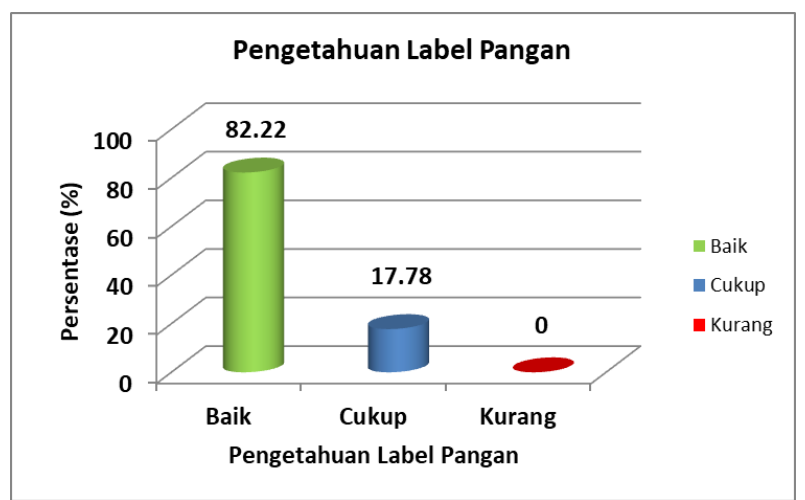

Gambar 5. Pengetahuan label pangan

Berdasarkan data pada Gambar 5 menunjukkan bahwa pengetahuan responden paling banyak ada pada kategoribaik $(82,22 \%)$, diikuti oleh kategori cukup berjumlah (17,78\%). Hasil ini menunjukkan bahwa pengetahuan responden sudah baik mengenai label pangan. Pengetahuan dari responden akan mempengaruhi proses keputusan pembelian suatu produk. Ketika responden mempunyai pengetahuan yang lebih banyak terkait label pangan, maka akan lebih baik dalam pengambilan keputusan dalam membeli produk. Hal ini menunjukkan bahwa dengan semakin tingginya semester belum tentu memiliki persepsi label pangan yang baik. Keputusan membeli atau mengkonsumsi suatu produk dengan merk dagang tertentu akan diawali oleh langkah-langkah seperti, pengenalan kebutuhan, pencarian informasi, dan evaluasi alternative [14].
Tingkat Kepatuhan dalam Membaca Label Pangan

Kepatuhan dalam membaca label pangan merupakan sebuah kebiasaan dari responden dalam membaca keterangan yang tertera pada label pangan kemasan. Tingkat kepatuhan membaca label pangan responden dibuat dengan pernyataan positif. Data mengenai tingkat kepatuhan responden dalam membaca label pangan dapat dilihat pada Gambar 6.

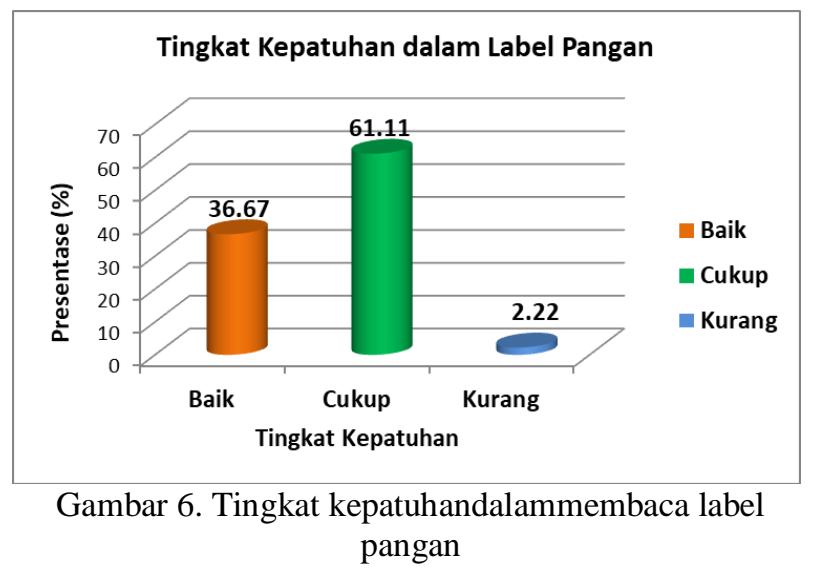

Berdasarkan data pada Gambar 6. Responden yang memiliki tingkat kepatuhan tertinggi berada pada kategori cukup mempunyai persentase terbesar yaitu $61,11 \%$, kategori baik 36,67\%, dan kategori kurang $2,22 \%$. Responden yang mempunyai tingkat kepatuhan dengan kategori cukup terbanyak ada pada mahasiswa semester 2. Kepatuhan mahasiswa dalam membaca label pangan pada kategori cukup $(72,22 \%)$, baik $(13,33 \%)$ dan kurang $(14,44 \%)$ [10]. Data pada penelitian ini menunjukkan bahwa mahasiswa belum terbiasa membaca label pangan ketika membeli suatu produk pangan kemasan.

Tingkat kepatuhan dalam membaca label pangan merupakan suatu indikator untuk mengetahui kebiasaan responden dalam membaca label pangan. Kategori baik dapat dilihat dengan membiasakan membaca label pangan seperti nama produk, alamat produsen, komposisi, keterangan halal, dan keterangan kadaluwarsa. Ada hubungan positif antara tingkat pengetahuan dengan praktik pemilihan makanan kemasan, dimana semakin tinggi tingkat pengetahuan responden, semakin baik dalam praktik pemilihan makanan kemasan [15]. Selain itu, tingkat kepatuhan dengan kategori baik dapat ditunjukkan dengan kebiasaan membaca informasi nilai gizi yang tertera pada produk pangan kemasan yang akan dibeli. Kepatuhan reponden dalam membaca label informasi zat gizi dan komposisi zat gizi ditemukan lebih tinggi pada 
responden yang berpengetahuan baik [16] Pengetahuan gizi yang baik akan mempermudah seorang konsumen dalam memahami dan membaca label gizi dengan sangat efisien[9].

Sebagai konsumen yang baik, apalagi mahasiswa yang merupakan agen perubahan bagi bangsa patut memberikan contoh kepada masyarakat dimulai dari hal-hal yang sederhana seperti membiasakan diri membaca label pangan sebelum membeli produk.

\section{KESIMPULAN}

Responden pada penelitian ini yang berjenis kelamin perempuan berjumlah 53,33\% dan laki-laki 46,67\%. Dari segi usia, sebagian besar responden berusia sekitar 19-21 tahun dengan persentase $82,22 \%$. Jika dilihat dari komponen uang saku responden per bulan, paling banyak uang saku per bulan dari responden sekitar Rp 800.000 - Rp 1.500 .000 yaitu $41,11 \%$. Keluarga dari responden berada pada criteria keluarga sedang yaitu berjumlah 5-7 orang dengan persentase $54,44 \%$. Pengetahuan responden paling banyak ada pada kategori baik yaitu $82,22 \%$. Hasil ini menunjukkan bahwa pengetahuan responden sudah baik mengenai label pangan. Responden yang memiliki tingkat kepatuhan tertinggi berada pada kategori cukup yaitu $61,11 \%$, kategori baik $36,67 \%$, dan kategorikurang $2,22 \%$.

Hasil survey menunjukkan tingkat kepatuhan responden dalam membaca label pangan masih pada kategori cukup. Oleh karena itu, perlu dilakukan sosialisasi atau edukasi di lingkungan kampus khususnya mahasiswa mengenai pentingnya membaca label pangan ketika akan membeli suatu produk pangan kemasan. Rekomendasi dari penelitian ini yaitu, diperlukan penyebaran kuisioner yang lebih luas mengenai tingkat kepatuhan dalam membaca label pangan kepada responden yang beragam dari segi usia, pekerjaan, dan tingkat pendidikan di lingkungan Sivitas akademika UAI agar mendapatkan gambaran pengetahuan dan tingkat kepatuhan responden dalam membaca label pangan dengan data yang komprehensif.

\section{UCAPAN TERIMA KASIH}

Terimakasih kami sampaikan kepada Lembaga Penelitian dan Pengabdian Masyarakat Universitas
Al Azhar Indonesia (LP2M UAI) dengan skemaStimulus Research Grant Tahun Ajaran 2018-2019.

\section{REFERENSI}

[1] Food and Drug Administration , "Enumeration of Eschericia coli and the Coliform bacteria," JOM FMIPA, vol. 1, p. 8, 2014.

[2] Badan Pengawas Obat dan Makanan, Label Olahan Pangan. Jakarta: BPOM, 2018.

[3] Badan Perlindungan Konsumen Nasional, Hasil Kajian Badan Perlindungan Konsumen Nasional di Bidang Pangan Terkait Perlindungan Konsumen. Jakarta: Departemen Perdagangan Republik Indonesia, 2007.

[4] Badan Pengawas Obat dan Makanan. (2015, Desember 2018) Keamanan Pangan Tanggung Jawab Bersama. [Online]. http://www.pom.go.id/mobile/index.php/vie w/pers/261/-quot-Kemanan-PanganTanggung-Jawab-Bersama-quot.html

[5] H. Umar, Metodologi Penelitian untuk Skripsi dan Tesis. Jakarta: Gramedia Pustaka, 2003.

[6] W. Budiaji, "Skala Pengukuran dan Jumlah Respon Skala Likert," Jurnal Ilmu Pertanian dan Perikanan, vol. 2, no. 2, pp. 127-1333, 2013.

[7] S. Consuelo G, Research Methods. Quenzon City: Rex Printing Company, 2007.

[8] P. Castillo L, R. Bordonada MA, and M. Geromini, "Information search behaviour, understanding and use of nutrition labeling by residents of Madrid, Spain.," Journal Public Health, vol. 129, no. 3, pp. 26-36, 2015.

[9] A. C. Drichoutis, Panagiotis Lazaridis, and Rodolfo Nayga, "Consumers' use of nutrition label: A review of research studies and issues," Academic of Marketing Science Review, vol. 10, no. 9, 2006.

[10] U. Sumawarman, Perilaku Konsumen "Teori dan Penerapannya dalam Pemasaran". Bogor: Ghalia Indonesia, 2014.

[11] Badan Koordinasi Keluarga Berencana Nasional, Gerakan Keluarga Berencana dan Keluarga Sejahtera. Jakarta: BKKBN, 1998.

[12] O.Biloukha;V Utermholen, "Healthy Eating in Ukraina: Attitude, Barries and Information Sources," Public Health Nutrition, vol. 4, no. 
2, pp. 207-2015, 2001.

[13] M. R Shepherd, The Psychology of Food Choiche. Cabi, 2006.

[14] P. S. Pane, "Analisis Tingkat Kepatuhan Membaca Label Pangan Pada Mahasiswa Gizi Institut Pertanian Bogor," Bogor, Skripsi 2016.

[15] V. C. Devi, A. Sartono, and J. Teguh Isworo, "Praktek Pemilihan Makanan Kemasan Berdasarkan Tingkat Pengetahuan Tentang Label Produk Makanan Kemasan, Jenis Kelamin, dan Usia Konsumen di Pasar Swalayan ADA Setiabudi Semarang," Jurnal Gizi Universitas Muhammadiyah Semarang, vol. 2, no. 2, 2013.
[16] S. Zahara and Triyanti, "Kepatuhan Membaca Label Informasi Zat Gizi di Kalangan Mahasiswa," National Public Health Journal, vol. 4, no. 2, 2009. 